\title{
Studies in the Renal Handling of Insulin in Juvenile Diabetics
}

\author{
K.P. Palmano and R. B. Elliott \\ Dept. of Paediatrics, School of Medicine, Univ. of Auckland, Auckland, New Zealand
}

Summary. A technique is described for the accurate radioimmunoassay of insulin ${ }^{1}$ in serum and urine. This method was applied to study of renal clearance and excretion of endogenous and exogenous insulin in untreated juvenile diabetics and healthy young adults. There was good agreement between our results for normal adults and previously reported values. In six non-obese juvenile diabetics, urinary insulin clearance values, both basal (fasting) and following glucose loading (entire range $0.03 \mathrm{ml} / \mathrm{min}$ to $1.23 \mathrm{ml} / \mathrm{min}$ ) were similar to those obtained for the adults (entire range $0.17 \mathrm{ml} / \mathrm{min}$ to $2.35 \mathrm{ml} / \mathrm{min}$ ). The basal urinary excretion in these diabetics was generally of the same order of magnitude as that in the normals. The clearance of exogenous insulin, administered for the first time, was also of the same order as that for endogenous insulin. Markedly elevated urinary clearance and excretion of insulin during fasting and non-fasting states was demonstrated in four non-obese juvenile diabetics with no clinical evidence of abnormal proteinuria, though they demonstrated slight to mild clinical dehydration and acidosis compared with the other diabetics studied. Clearance and excretion of exogenous insulin was similarly elevated. This finding could reflect renal tubular dysfunction in these diabetics, and this dysfunction could relate to even the mild degree of dehydration and acidosis found in this study. Endogenous and exogenous insulin clearance in an obese diabetic child was similar to that for the control group.

Key words: Glucose tolerance, insulin excretion, juvenile diabetes, proximal tubule, radioimmunoassay, urinary insulin clearance.

1 Citations of insulin refer to insulin-like immunoreactivity
Although the urinary excretion and clearance of insulin have been studied in normal [1-6] and disease states $[1,2,7,7 \mathrm{~A}, 8,9]$, there are relatively few reports documenting these parameters in children [5, $10,11]$, and only fragmentary reports have appeared concerning the renal handling of insulin in children with juvenile onset diabetes $[2,4,9,10]$. We have therefore investigated, as well as practicably possible, the urinary excretion and clearance of endogenous and exogenous insulin in recently diagnosed untreated juvenile diabetics in an attempt to throw some light on the kidney handling of insulin in this type of diabetic.

\section{Material and Methods}

\section{Radioimmunoassay}

To facilitate renal clearance studies a radioimmunoassay for insulin in ruine and serum was adapted from the coated charcoal method of Herbert et al. [12] as described essentially by Albano et al. [12a] for use on both serum and urine. Albumin was used as the coating agent. Initial studies showed low recovery of insulin added to urine. This low recovery was found to be a function of non-specific adsorption of insulin to container walls, which could be overcome by addition of albumin to the urine, and precautionary measures taken to overcome adsorption to and coprecipitation with urinary sediments. The details of the assay and the collection of samples are described in a appendix.

\section{Clearance Studies}

The relationship between serum insulin and urinary insulin was studied by determining insulin clearance during fasting and following glucose loading, as a means of affording both basal and elevated circulating insulin levels. 
Table 1. Clinical details of juvenile diabetics studied. Results of analyses performed on admission to hospital

\begin{tabular}{|c|c|c|c|c|c|c|c|c|c|c|}
\hline Subject & Sex & $\begin{array}{l}\text { Age } \\
\text { yrs. }\end{array}$ & $\begin{array}{l}\text { Wgt } \\
\mathrm{kg}\end{array}$ & $\begin{array}{l}\text { Clinical } \\
\text { dehydration }\end{array}$ & $\begin{array}{l}\text { Clinical } \\
\text { acidosis }\end{array}$ & $\begin{array}{l}\text { Blood. } \\
\text { glucose } \\
\mathrm{mg} / 100 \mathrm{ml}\end{array}$ & $\begin{array}{l}\text { Blood } \\
\mathrm{pH} \\
1\end{array}$ & $\begin{array}{l}\text { Glycosuria } \\
\mathrm{g} / 100 \mathrm{ml}\end{array}$ & $\begin{array}{l}\text { Ketonuria } \\
\mathrm{g} / 100 \mathrm{ml}\end{array}$ & $\begin{array}{l}\text { Proteinuria } \\
\text { (see text) }\end{array}$ \\
\hline K.B. & $\mathbf{M}$ & 12 & 30.9 & $0^{\mathrm{a}}$ & 0 & 232 & $-{ }^{b}$ & 5.6 & 1.0 & 0 \\
\hline B.C. & $\mathrm{F}$ & 12 & 50 & 0 & 0 & 282 & 7.45 & 3.5 & 1.0 & 0 \\
\hline \multicolumn{11}{|c|}{$\begin{array}{l}\text { Overweight } 2 \text { yrs } \\
\text { previously }\end{array}$} \\
\hline $\mathrm{K}, \mathrm{J}$. & $\mathrm{F}$ & 9 & 21.6 & 0 & 0 & 480 & 7.42 & 2.0 & 0 & 0 \\
\hline M.M. & M & $1 \frac{1}{4}$ & 10.77 & 0 & 0 & 183 & - & 1.0 & 0 & 0 \\
\hline N.R. & $\mathbf{M}$ & 12 & 42.5 & 0 & 0 & 180 & 7.37 & 3.0 & 4.0 & 0 \\
\hline \multicolumn{11}{|l|}{$\begin{array}{l}\text { Mildly } \\
\text { overweight }\end{array}$} \\
\hline C.S. & $\mathrm{F}$ & 12 & 35.0 & 0 & 0 & 700 & 7.36 & 3.0 & 0 & 0 \\
\hline G.W. & $\mathbf{M}$ & 2 & 14.4 & 0 & 0 & 302 & - & 2.0 & 3.5 & 0 \\
\hline E.F. & $\mathbf{M}$ & 14 & 40 & $3 \%$ & 0 & 324 & 7.22 & 1.0 & 3.5 & 0 \\
\hline J.J. & $\mathbf{M}$ & 10 & 24.7 & $3 \%$ & 0 & 483 & 7.34 & 2.0 & 3.5 & 0 \\
\hline K.M. & $\mathbf{M}$ & 12 & 38 & $2 \%$ & + & 483 & 7.30 & 2.0 & 3.5 & 0 \\
\hline D.N. & M & $51 / 2$ & 18 & $5 \%$ & + & 254 & 7.26 & 2.0 & 1.0 & 0 \\
\hline W.K. ${ }^{c}$ Obese & $\mathrm{F}$ & 12 & 90.8 & 0 & 0 & 271 & 7.38 & 8.2 & 1.0 & 0 \\
\hline
\end{tabular}

${ }^{\text {a }}$ Not present

${ }^{b}$ Not determined

c Obesity diagnosed as clinical cause of diabetes

Insulin clearance was also investigated following administration of insulin. Creatinine clearance was determined as an index of glomerular filtration rate (GFR).

\section{Subjects}

a. Diabetics. Eleven children with recently diagnosed juvenile onset diabetes mellitus of different severity, but not in need of immediate therapy, were studied upon admission to hospital. Most were admitted with histories of polyuria, polydipsia and recent weight loss and all had elevated blood glucose levels and impaired glucose tolerance. There was no evidence of abnormal proteinuria in any, and urinalyses, apart from glucose and ketones, were normal. 4 children had mild clinical dehydration, and mild depression of blood $\mathrm{pH}$. Clinical details are given in Table 1. A twelfth diabetic was extremely obese and, as her diabetes was subsequently controlled by diet and sulphonylureas, she has been considered separately.

Oral glucose tolerance tests (GTT) were performed on six diabetics, with urine and blood sampling as described in the appendix. In addition, timed urine samples of varying duration, both fasting and postprandial (nonfasting) were obtained from those other diabetics on whom GTT was not performed. Where possible, fasting and nonfasting blood samples were also drawn at periods during these collections to allow of mean clearance determinations. For ethical reasons, sampling was necessarily opportinistic, and creatinine clearance rather than a more precise clearance technique was used.

Urine and blood samples were also collected for a number of diabetics following administration of insulin (see appendix).

$b$. Normals. As it was difficult to obtain a representative group of normal children as control subjects, a group of healthy young adults was used to afford at least some criterion of comparison. This group consisted of five males and three females between the ages of 18 and 31 years (mean 20 year) with no evidence of endocrine disorders or familial history of diabetes. All underwent glucose tolerance testing and, in addition, five underwent subsequent insulin tolerance testing (ITT).

We were able, however, to obtain for our study three completely normal children of ages 6,9 , and 12 years on whom GTT were performed.

Comparison of results for these children and adults (discussed below) indicated a similarity of renal handling of insulin between the age groups and afforded some justification in using the combined normal group as controls for the diabetics.

\section{Results}

Clearances were calculated usint approximated mean serum levels derived for each collection period. Where random diabetic urines were collected, clearances were calculated using mean serum levels derived from samples drawn during the collection. Because of sampling inconsistencies and rapidly changing serum insulin levels, the mean clearance over the entire GTT period (excluding fasting) for each subject is presented together with the fasting data. As GFR 
Table 2. Urinary clearance and excretion of endogenous insulin in healthy young adults (and 3 healthy children) during fasting and following oral glucose loading

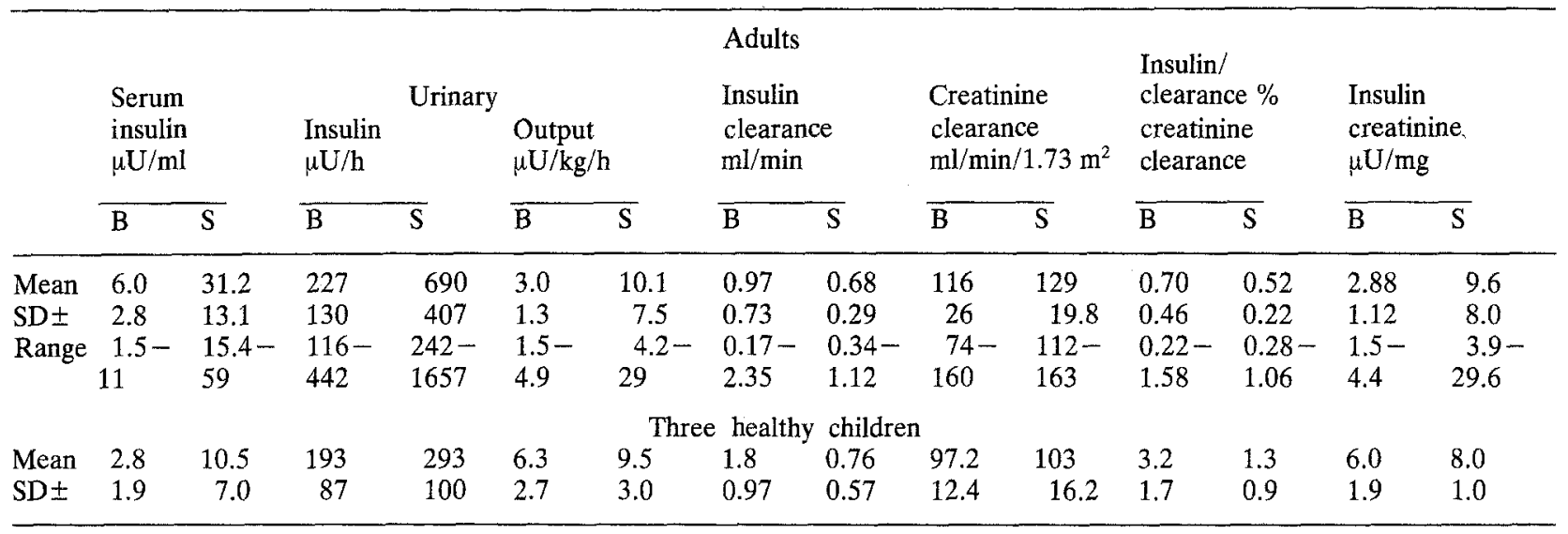

$\mathrm{B}=$ Basal (fasting) state

$\mathrm{S}=$ Stimulated (GTT) state. All values in these columns represent mean values for the GTT period

Table 3. Urinary clearance and excretion of exogenous insulin in healthy young adults (mean values over ITT period)

\begin{tabular}{llllll}
\hline $\begin{array}{l}\text { Serum } \\
\text { insulin } \\
\mu \mathrm{U} / \mathrm{ml}\end{array}$ & $\begin{array}{l}\text { Urinary } \\
\text { insulin } \\
\text { output } \\
\mu \mathrm{U} / \mathrm{h}\end{array}$ & $\begin{array}{l}\text { Insulin } \\
\text { clearance } \\
\mathrm{ml} / \mathrm{min}\end{array}$ & $\begin{array}{l}\text { Creatinine } \\
\text { clearance } \\
\mathrm{ml} / \mathrm{min} / 1.73 \mathrm{~m}^{2}\end{array}$ & $\begin{array}{l}\text { Ins. clearance } \\
(\%) \\
\text { Creatinine } \\
\text { clearance }\end{array}$ & $\begin{array}{l}\text { Insulin/ } \\
\text { Creatinine } \\
\mu \mathrm{U} / \mathrm{mg}\end{array}$ \\
\hline Mean 32.1 & 275 & 0.26 & 110.6 & 0.23 & 4.4 \\
SD士 19.3 & 101 & 0.11 & 4.4 & 0.09 & 0.88 \\
Range 7.3-58.3 & $147-436$ & $0.07-0.40$ & $107-116$ & $0.07-0.36$ & $3.3-4.8$ \\
\hline
\end{tabular}

varies with body size [15], insulin excretion has also been expressed relative to creatinine excretion. This has the added advantage in that it allows for inaccuracies in urine collections as well as correcting for differences in body weight. Although a correction for body weight between diabetics and normal adults can be made, there is no such correction factor for age and therefore no strict correlation between the two groups can be made. However, Najjar and Stephan [5] have found no significant difference between urinary insulin excretion in children and adults, and from our limited data it would appear that the renal handling of insulin in normal children is similar to that for adults.

Creatinine clearances for healthy young adults and children (Tables 2 and 3) corresponded with reported values [16] and most values for diabetics (Tables 4 and 5), when corrected to a standard body surface area of $1.73 \mathrm{~m}^{2}$, fell within the normal range. In all diabetics studied the actual excretion of creatinine, expressed as $\mathrm{mg} / \mathrm{kg} / \mathrm{h}$ (not shown), was within the range of that documented for healthy children [17], and where an apparently low clearance was found this related to an elevated serum creatinine [Doolan et al., 16]. In the two obvious examples of apparent low clearance of creatinine, the insulin/creatinine indices must be interpreted with caution, though not affecting the absolute insulin excretion rates. Creatinine clearance did not relate to any of the clinical parameters shown in Table 1 , though this does not exclude a technical artefact of serum creatinine determination in some diabetics.

\section{Urinary Insulin Clearance in Healthy Young Adults}

Data for urinary clearance and excretion of endogenous insulin in normal adults, both basal and following glucose loading, are given in Table 2 . The overall mean value for serum insulin increased during GTT (shown on table). An expected and corresponding increase in urinary insulin output was observed also. Insulin clearance remained relatively constant throughout. This constancy of clearance over a range of plasma insulin levels has previously been reported $[2,3,6,8]$ and the range of endogenous insulin clearance observed in this study $(0.17-2.35 \mathrm{ml} / \mathrm{min})$ is consistent with that of Chamberlain and Stimmler [1].

Relating insulin clearance to creatinine clearance does not appreciably alter values or interpretation of results. 
Table 4. Urinary clearance and excretion of endogenous insulin in juvenile diabetics during fasting and non-fasting, and following oral glucose loading

\begin{tabular}{|c|c|c|c|c|c|c|c|c|c|c|c|c|c|c|c|}
\hline & \multirow[t]{2}{*}{ Subject } & \multicolumn{2}{|c|}{$\begin{array}{l}\text { Serum } \\
\text { insulin } \\
\mu \mathrm{U} / \mathrm{ml}\end{array}$} & \multicolumn{2}{|c|}{$\begin{array}{l}\text { Urinary } \\
\text { insulin } \\
\mu \mathrm{U} / \mathrm{h}\end{array}$} & \multicolumn{2}{|c|}{$\begin{array}{l}\text { Output } \\
\mu \mathrm{U} / \mathrm{kg} / \mathrm{h}\end{array}$} & \multicolumn{2}{|c|}{$\begin{array}{l}\text { Insulin } \\
\text { clearance } \\
\mathrm{ml} / \mathrm{min}\end{array}$} & \multicolumn{2}{|c|}{$\begin{array}{l}\text { Creatinine } \\
\text { clearance } \\
\mathrm{ml} / \mathrm{min} / 1.73 \mathrm{~m}^{2}\end{array}$} & \multicolumn{2}{|c|}{$\begin{array}{l}\text { Insulin } \\
\text { clearance \% } \\
\text { Creatinine } \\
\text { clearance }\end{array}$} & \multicolumn{2}{|c|}{$\begin{array}{l}\text { Insulin } \\
\text { creatinine } \\
\mu \mathrm{U} / \mathrm{mg}\end{array}$} \\
\hline & & $\overline{\mathrm{B}}$ & $\bar{S}$ & $\overline{\mathbf{B}}$ & $\overline{\mathrm{S}}$ & $\overline{\mathrm{B}}$ & $\overline{\mathrm{S}}$ & $\overline{\mathrm{B}}$ & $\bar{S}$ & $\overline{\mathrm{B}}$ & $\overline{\mathrm{S}}$ & $\overline{\mathrm{B}}$ & $\bar{S}$ & $\overline{\mathbf{B}}$ & $\overline{\mathrm{S}}$ \\
\hline & B.C. & - & $23^{\mathrm{a}}$ & - & 291 & - & 5.8 & - & 0.21 & - & 151 & - & 0.18 & - & 4.1 \\
\hline & K.J. & 5.5 & 4.5 & 164 & 110 & 7.4 & 5.1 & 0.49 & 0.37 & 109 & 83.4 & 0.44 & 0.29 & 3.1 & 6.3 \\
\hline Group & M.M. & 5.5 & $5.5^{\mathrm{b}}$ & 65 & 33.7 & 5.4 & 3.1 & 0.03 & 0.10 & 134 & 136.4 & 0.08 & 0.07 & 2.0 & 1.3 \\
\hline A & N.R. & 10 & 15 & 84 & 218 & 1.98 & 5.1 & 0.14 & 0.31 & 44 & 82.7 & 0.4 & 0.52 & 4.5 & 8.1 \\
\hline & C.S. & 4.5 & - & 262 & - & 7.4 & - & 0.97 & - & 77.5 & - & 1.9 & - & 6.2 & - \\
\hline & G.W. & 1.0 & 1.0 & 0.4 & 29 & 0.3 & 2.0 & 0.14 & 1.23 & 28.5 & 26.7 & 1.4 & 13.8 & 0.06 & 5.8 \\
\hline & E.F. & 5 & 5 & 2418 & 2317 & 60.4 & 57.9 & 7.8 & 7.7 & 65 & 110 & 16.3 & 9.5 & 94 & 53.3 \\
\hline & J.J. & - & $1.0^{c}$ & - & 3450 & - & 139 & - & 16.8 & - & 90.1 & - & 18 & - & 94 \\
\hline Group & K.M. & 5 & 2.5 & 2773 & 4928 & 72.9 & 130 & 9.2 & 34.4 & 13.6 & 19.6 & 191 & 175 & 219 & 213 \\
\hline B & D.N. & 4.5 & - & 2320 & - & 129 & - & 8.6 & - & 82 & - & 25.8 & - & 116 & - \\
\hline $\begin{array}{l}\text { Obese } \\
\text { Diabeti }\end{array}$ & $\begin{array}{l}\text { W.K. } \\
\text { tic }\end{array}$ & 23 & 23 & 184 & 118 & 2.0 & 1.3 & 0.10 & 0.04 & 59.4 & 46 & 0.16 & 0.08 & 3.1 & 2.7 \\
\hline
\end{tabular}

a Samples taken during postprandial 7 hour urine collect.

b Samples taken during 20 hour 'non-fasting' urine collect.

c Samples taken during 18 hour 'non-fasting' urine collect.

$\mathrm{B}=$ Basal (fasting) state

$\mathrm{S}=$ Stimulated (GTT) state unless otherwise indicated

Blanks indicate where samples not available.

The basal and mean post-glucose urinary insulin clearance and excretion values for the three normal children are within the adult range.

Urinary clearance of exogenous insulin in normals (Table 3) remained relatively constant over the ITT period. There was no significant difference $(\mathrm{P}>0.05)$ between the exogenous and endogenous insulin clearances, though the former tended to be lower. The lesser clearance values may be associated with serum insulin levels which were generally persistently higher. It has been previously noted that at peak serum insulin levels, insulin clearance is at or approaching its lowest value $[1,2]$.

\section{Urinary Clearance and Excretion of Insulin in Juvenile Diabetics}

For one diabetic (K.B.) no endogenous insulin could be detected in either urine or serum. The remaining nonobese juvenile diabetics were classified into two groups on the basis of results obtained (Table 4). Statistical analyses within and between groups was not attempted as there was insufficient data in the subgroups for analysis.

Group A consisted of those diabetics whose clearance of insulin over fasting, non-fasting and GTT periods was within our normal range. Basal serum insulin levels in four subjects were low, about 5 $\mu \mathrm{U} / \mathrm{ml}$, and did not increase in response to glucose loading. However, in two of the Group A diabetics
B.C. and N.R. (Table 4), serum insulin appeared somewhat elevated in comparison. It is interesting to note that B.C. had been obese two years previously and N.R. was still obese despite recent weight loss. In two cases (N.R. \& G.W.) urinary insulin excretion increased after glucose loading.

Relative to body weight and GFR, diabetics in this group showed a level of excretion similar to adults. The mean fasting output $(115 \mu \mathrm{U} / \mathrm{h} \pm 89)$ for five Group A diabetics was less than corresponding values published by Najjar and Stephan [5] for seven normal children 1 to 5 years old $(149 \mu \mathrm{U} / \mathrm{h} \pm 62.45)$ and twenty normal children 6 to 15 years old $(172 \mu \mathrm{U} / \mathrm{h} \pm$ 57.62). The mean basal output for three normal children in our study was $193 \mu \mathrm{U} / \mathrm{h} \pm 87$.

Group B consisted of four juvenile diabetics in whom excessively high urinary clearance and excretion of insulin was observed in basal and stimulated states (Table 4). Each parameter describing the insulin excretion index was markedly increased above the corresponding parameter for both the adults and Group A diabetics. However, serum insulin levels wer low (range $1-5 \mu \mathrm{U} / \mathrm{ml}$ ) in all cases.

In one diabetic, K. M., insulin clearance exceeded creatinine clearance, but this was probably a function of depressed creatinine clearance as discussed earlier.

For an obese diabetic, W.K. (Table 4), fasting serum insulin was above normal. There was no increase in either serum insulin or urine insulin in response to glucose loading. Urinary insulin clearance 
Table 5. Urinary clearance and excretion of exogenous insulin in juvenile diabetics (mean values over ITT period)

\begin{tabular}{|c|c|c|c|c|c|c|c|}
\hline & Subject & $\begin{array}{l}\text { Serum insulin } \\
\mu \mathrm{U} / \mathrm{ml}\end{array}$ & $\begin{array}{l}\text { Urinary } \\
\text { insulin output } \\
\mu \mathrm{U} / \mathrm{h}\end{array}$ & $\begin{array}{l}\text { Insulin } \\
\text { clearance } \\
\mathrm{ml} / \mathrm{min}\end{array}$ & $\begin{array}{l}\text { Creatinine } \\
\text { clearance } \\
\mathrm{ml} / \mathrm{min} / 1.73 \mathrm{~m}^{2}\end{array}$ & $\begin{array}{l}\text { Ins. clearance } \\
(\%) \\
\text { Creatinine } \\
\text { clearance }\end{array}$ & $\begin{array}{l}\text { Insulin/ } \\
\text { Creatinine } \\
\mu \mathrm{U} / \mathrm{mg}\end{array}$ \\
\hline Group & K.J. & 30 & 426 & 0.59 & 61.9 & 2.0 & 50 \\
\hline \multirow[t]{2}{*}{ A } & C.S. & 38 & 1089 & 0.57 & 80.2 & 1.1. & 8.4 \\
\hline & K.B. & 37.1 & 736 & 0.35 & 66.4 & 0.87 & 23.1 \\
\hline Group & E.F. & 59.5 & 22,782 & 5.4 & 100 & 8.4 & 210 \\
\hline \multirow[t]{2}{*}{ B } & K.M. & 22 & 27,200 & 40.3 & 11.8 & 341 & 1250 \\
\hline & D.N. & 63 & 57,510 & 38.3 & 89 & 102 & 7281 \\
\hline $\begin{array}{l}\text { Obese } \\
\text { Diabetic }\end{array}$ & W.K. & 57.7 & 271 & 0.08 & 105 & 0.07 & 4.4 \\
\hline
\end{tabular}

and excretion were of the same order as in adults and Group A diabetics.

A true correlation between clearance and excretion of endogenous and exogenous insulin in diabetics was not possible as there was insufficient data. In all cases, an expected increase in serum insulin following insulin administration was accompanied by a corresponding increase in urinary insulin (Table 5). Of the three Group A diabetics studied, two (K.J. and C.S.) demonstrated insulin clearances comparable with those for their own insulin, while for a third (K. B.), in whom endogenous insulin clearance could not be determined as serum levels were below the detection limit, subsequent exogenous insulin clearance $(0.35$ $\mathrm{ml} / \mathrm{min}$ ) was of the same order as the other two.

The three Group B diabetics tested showed increased exogenous insulin clearance and output comparable to their endogenous clearance and outputs.

In the obese diabetic, exogenous insulin clearance was similar to endogenous insulin clearance.

All four Group B diabetics showed signs of slight or mild clinical dehydration, and biochemically measured acidosis, compared with Group $\mathrm{A}$ or $\mathrm{C}$ who showed no signs of clinical dehydration or acidosis, or, where measured, biochemical acidosis. Creatinine clearance did not relate to these differences in clinical status, nor did urinary protein, or ketone concentrations, or the serum/urine glucose ratio.

\section{Discussion}

Most of the previous studies of the renal handling of insulin in man conclude that insulin is filtered freely at the glomerulus and then largely reabsorbed or destroyed in the proximal tubule $[1,7,8]$. Insulin clearance alters little over a wide range of plasma insulin values $[1,3,6]$, indicating that the proximal tubules have a high reabsorptive or destructive capacity. Our data for normal adults and children are consistent with these observations $[1,3,5,6]$.
Of the 11 non-obese juvenile diabetics studied, 4 demonstrated notably elevated urinary insulin clearance and excretion in basal and non-fasting states. The basal urinary insulin excretion rate alone was well in excess of both fasting and non-fasting values reported for healthy children $[5,10]$ and our own limited data on normal children. This apparent hyperinsulinuria was not due to elevated serum endogenous insulin levels. However, the high clearance values were not determined by the latter, as low serum insulin was also a feature of the Group A diabetics in whom 'normal' clearance was observed. McArthur and Stimmler [10] have shown that in siblings of childhood onset diabetics, urinary insulin excretion is distributed into two groups; those with normal, and those with 'elevated' urinary insulin levels. However, the latter authors did not measure plasma insulin levels. In addition, Najjar and Stephan [5] have reported high values of urinary $\mathrm{IRI}^{2}$ in four children each with one diabetic parent, but these subjects demonstrated elevated plasma IRI in response to oral glucose load.

Since high clearances and excretion were also noted for exogenous insulin in Group B, the abnormalities would appear to be a function of altered renal handling in these diabetics.

It has been suggested that hyperinsulinuria and subsequent excessive clearance of insulin in the face of hypoinsulinaemia is indicative of impaired function of the proximal renal tubule $[1,2,7 \mathrm{a}]$. Elevated urinary insulin levels have been found in patients with known renal tubular disorders $[1,2,7 \mathrm{a}]$. However, in the absence of clinically diagnosable renal abnormalities in the majority of the diabetics studied, it is interesting to speculate whether, in fact, high urinary insulin is a result of selective or impaired tubular reabsorption; or enhanced glomerular permeability. The latter is unlikely as normal values for urinary insulin clearance and excretion have been observed in patients with

2 Immunreaktive Insulin 
severe glomerular lesions and massive proteinuria, such as the nephrotic syndrome $[1,8]$.

The presence of abnormal insulin excretion and clearance did appear to be related to a mild degree of clinical dehydration and acidosis but not to ketonuria or glycosuria at the time of admission to hospital, but the duration of the abnormality before the onset of overt diabetes is not known. Studies after the initiation of insulin therapy are confused by uncertainty of the form and origin of circulating I.R.I. At 1 year of follow up, the insulin requirement $/ \mathrm{Kg}$ body weight in Groups A and B was very similar. This implies that the insulinuria is not of sufficient magnitude or duration to alter insulin requirements at this interval and, indeed, the maximum urinary loss demonstrated (55.5 milliunits/hr), even if sustained throughout 24 hours, would be only a small portion of the daily insulin requirement. The relation ship, if any, of excess loss of insulin (or other low molecular weight substances) in the urine to the presence or development of early chronic renal changes awaits further study.

Acknowledgments. This work was supported by the Medical Research Council of New Zealand. We would like to thank the Medical Staff of the Princess Mary Hospital for Children, Auckland, for their valuable assistance.

\section{Appendix}

\section{Materials and Method}

Dilution Media. All dilutions of antisera, insulin standard and radioactive hormone were performed using $0.05 \mathrm{M}$ phosphate buffer $\mathrm{pH} 7.4$, containing $0.3 \%$ BSA (albumin phosphate buffer).

Albumin. Bovine serum albumin powder (BSA) Fraction V. (Obtained from Armour Pharmaceuticals).

Insulin. Lyophilised human insulin (obtained from Wellcome Reagents Limited, Beckenham, England) was used for preparing standard insulin solutions. These standards wer stored at $-20^{\circ} \mathrm{C}$.

Insulin Antibody. Lyophilised guinea-pig anti-insulin serum (Wellcome Reagents Limited) was obtained in batches (K 1769 and $\mathrm{K} \mathrm{3481}$ ) and stored at $4^{\circ} \mathrm{C}$. It was diluted on the day of use.

${ }^{125}$ I-Insulin. ${ }^{125} \mathrm{I}$ labelled porcine insulin, specific activity about $180 \mu \mathrm{Ci} / \mu \mathrm{g}$, was prepared according to minor procedural adaptations of the method of Hunter and Greenwood [13]. Aliquots of the stock solution were stored frozen at $-20^{\circ} \mathrm{C}$. These were thawed and freshly diluted immediately before use.

Insulin Free Plasma. To minimise the effect of variable non-specific factors on antibody binding and charcoal adsorption characteristics, and ensure a greater uniformity of incubation media in all tubes, insulin free plasma (IFP) was added to each incubation medium except those containing test sera. IFP was prepared according to the method of Herbert et al. [12] and stored in aliquots at $-20^{\circ} \mathrm{C}$.

Charcoal Suspension. Just prior to separation of 'free' from antibody bound hormone, a $3.5 \%$ w.v. solution of activated charcoal (series 33032 obtained from BDH Chemicals Ltd) in albumin phosphate buffer was prepared. Suspension of the charcoal powder was achieved by magnetic stirring for a minimum of $30 \mathrm{~min}$.

\section{Determination of Insulin}

Insulin determinations were carried out in duplicate. Total assay volume was $1 \mathrm{ml}$. To assay tubes containing albumin phosphate buffer was added $0.1 \mathrm{ml}$ IFP, $0.1 \mathrm{ml}$ human insulin standard (concentration range $0-100 \mu \mathrm{U} / \mathrm{ml}$ ) or test sample, and $0.1 \mathrm{ml}$ antiinsulin serum, Batch K 3481 diluted 1: 37500 . (In the case of test sera, IFP was omitted.) The contents of the tubes were mixed (using a Vortex mixer) between additions and a pre-incubation time of 20-30 minutes allowed for insulin-antibody contact before addition of ${ }^{125} \mathrm{I}$-insulin diluted to a concentration of $0.5 \mathrm{ng} / \mathrm{ml}$. After a final mixing, the tubes were incubated for 16 hours overnight at $4^{\circ} \mathrm{C}$. Separation of the antibody bound and 'free' ${ }^{125} \mathrm{I}$-insulin was achieved by addition of $0.5 \mathrm{ml}$ coated charcoal suspension to each tube, mixing, and centrifugation for 20 minutes at $1600 \times \mathrm{g}$ $\left(4^{\circ} \mathrm{C}\right)$. The supernates were removed by vacuum suction and the radioactivity remaining in the charcoal button was counted in a Selektronic solid crystal welltype gamma radiation counter. Test control tubes containing every reagent except anti-insulin serum and standard were included in each assay and the test results calculated as a percentage of these. A dose response curve was constructed by plotting the concentration of insulin standard added against percentage 'free' (non-antibody bound) ${ }^{125}$ I-insulin.

The sensitivity of the assay over the $0-10 \mu \mathrm{U} / \mathrm{ml}$ range of insulin concentration was optimised by using different dilution and incubation conditions: anti-insulin serum (Batch K 1769) at a dilution of $1: 60000$; ${ }^{125} \mathrm{I}$-insulin at a concentration of $0.25 \mathrm{ng} / \mathrm{ml}$ and incubation for 3 days at $4^{\circ} \mathrm{C}$. Very good agreement (coefficient of variation $2 \%$ ) was obtained between the two assay systems over their coincident sensitive ranges. The lower limit of accurate measurement for test samples was $1.0 \mu \mathrm{U} / \mathrm{ml}$ of incubation mixture and the coefficient of variation for measurements over the range $1-80 \mu \mathrm{U} / \mathrm{ml}$ was between 0.2 and $2 \%$. Between assay replication was assessed as $\pm 7 \%$.

\section{Glucose Tolerance Tests}

Subjects were fasted overnight for a minimum of 8 hours and standard $2 \mathrm{hr}$ GTT performed. Timed fasting urine samples and fasting blood were taken prior 
to oral glucose administration (50 g for adults and a dose dependent on body weight [14] for children). Thereafter urine samples were taken at 30,60 and 120 min with blood sampling midway through each collection period. The importance of complete bladder emptying was stressed when appropriate.

Several diabetics were given $500 \mathrm{ml}$ of water an hour prior to the GTT to increase urine flow. Modifications of sampling times were sometimes necessary in very young patients.

\section{Insulin Tolerance Tests}

These were performed in normals after an overnight fast. Fasting blood and urine samples were taken, followed by subcutaneous administration of 5 Units of soluble insulin. Further timed blood and urine samples were taken, as for GTT, over a period of four hours. For diabetics, the same format was followed except that a variable dose of soluble insulin was given for initial stabilisation. In those cases when glucose tolerance testing was performed, it was necessary to administer insulin on the same day following assumed return to basal physiological conditions. In most cases sampling was again opportunistic.

Blood was drawn by venepuncture. Aliquots of serum and urine were analysed for creatinine and insulin. Creatinine was measured by automatic colorimetry (Technicon Autoanalyser).

\section{Collection, Treatment and Assay of Urine}

Urines were collected into polythene containers and stored at $4^{\circ} \mathrm{C}$ until centrifugation $(1670 \times \mathrm{g}, 10 \mathrm{~min}$ $4^{\circ} \mathrm{C}$ ) prior to assay on the same day. Where storage was necessitated, BSA ( $1 \%$ w.v.) was added to the fresh specimen following centrifugation and the sample stored frozen at $-20^{\circ} \mathrm{C}$. On thawing, any urinary sediment formed was resuspended and volumes assayed as in standard procedure for test samples. This procedure gave full rocovery of insulin.

To allow of effective dilution and concentration of urine, sample volumes between $0.01 \mathrm{ml}$ and $0.3 \mathrm{ml}$ were added at the expense of the dilution medium. Over this range the effect of salt concentration and $\mathrm{pH}$ were shown not to interfere with the assay.

\section{Urinary Protein}

Urinary protein was carried out by an automated turbidometric technique employing sulphosalicylic acid. The method has a detection limit of $10 \mathrm{mg} / 100 \mathrm{ml}$ coefficient of variance of $3 \%$ over the range $50-750$ $\mathrm{mg} / 100 \mathrm{ml}$.

\section{References}

1. Chamberlain, M.J., Stimmler, L.: The renal handling of insulin. J. clin. Invest. 46, 911-919 (1967)

2. Rubenstein, A.H., Lowy, C., Russell Fraser, T.: Radioimmunoassay of insulin in urine. Diabetologia 3, 453-459 (1967)
3. Rubenstein, A.H., Lowy, C., Welborn, T. A., Russell Fraser, T.: Urine insulin in normal subjects. Metabolism 16, 234-244 (1967)

4. Jorgensen, K.R.: Immunoassay of insulin in human urine. Acta endocr. (Kbh.) 51, 400-410 (1966)

5. Najjar, S.S., Stephan, L.: Urinary insulin II. Excretion in children and adults. Metabolism 19, 301-308 (1970)

6. Orskov, H., Johansen, K.: Immunological measurements of urinary insulin for the evaluation of insulin production. Acta endocr. (Kbh.) 71, 697-708 (1972)

7. Ching, K.N., Karam, J.H., McSherry, E., Morris, R.C., Epstein, W.V.: Hyperinsulinuria - an index of renal tubular disorders. Clin. Res. 19, 194 (1971)

7a. Ching, K.N., Karam, J.H., Choy, F.B., Kolb, F.O., Grodsky, G.M., Forsham, P.H.: Hyperinsulinuria in patients with renal calculi. Clin. chim. Acta 40, 383-389 (1972)

8. Spitz, I.M., Rubenstein, A.H., Bersohn, I., Wright, A.D., Lowy, C.: Urine insulin in renal disease. J. Lab. clin. Med. 75, 998-1005 (1970)

9. Jorgensen, K.R.: Radioimmunoassay of insulin in plasma and urine in obese subjects and in diabetic patients. Acta endocr. (Kbh.) 60, 719-736 (1969)

10. McArthur, R.G., Stimmler, L.: Urinary insulin excretion in healthy children and in siblings of childhood onset diabetics. Lancet 1966 I, 1236-1237

11. Lowy, C., Schiff, D.: Urinary excretion of insulin in the healthy newborn. Lancet 1968 I, 225-227

12. Herbert, V., Lau, K. S., Gottlieb, C. W., Bleicher, S. J.: Coated charcoal immunoassay of insulin. J. clin. Endocr. 25, 1375-1384 (1965)

12a. Albano, J.D.M., Ekins, R.P., Maritz, G., Turner, R.C.: A sensitive, precise radioimmunoassay of serum insulin relying on charcoal separation of bound and free hormone moieties. Acta endocr. (Kbh.) 70, 487-509 (1972)

13. Hunter, W.M., Greenwood, F.C.: Preparation of Iodine -131 labelled human growth hormone of high specific activity. Nature (Lond.) 194, 495-496 (1962)

14. O'Brien, D., Ibbott, F.A., Rodgerson, D. O.: Laboratory manual of paediatric microbiochemical techniques. Hoeber Medical Division, Harper and Row Publishers, Inc., pp. 310-311 (1968)

15. Robinson, J. R.: Principles of renal physiology. In: Renal disease (ed. D.A.K. Black), pp. 55-56. Oxford: Blackwell Scientific Publications 1962

16. Doolan, P.D.C., Alpen, E.L., Theil, G.B.: A clinical ap praisal of the plasma concentration and endogenous clearance of creatinine. Amer. J. Med. 32, 65-79 (1962)

17. Kennedy, W.P.: Creatine, creatinine and total body potassium in relation to muscle mass in children. Arch. Dis. Childh, 36, 325-327 (1961)

18. Robinson, G.C., McDonnell, D.: Simultaneous onset of diabetes mellitus and nephrotic syndrome. Canad. med. Ass. J. 85, 80-81 (1961)

19. Ellenberg, M.: Diabetic nephropathy presenting as the initial clinical manifestation of diabetes. Ann. intern. Med. 49, 620-631 (1968)

20. Urizar, R.E., Schwartz, A., Tan, F., Vernier, R.L.: The nephrotic syndrome in children with diabetes mellitus of recent onset. New Engl. J. Med. 281, 173-181 (1969)

Received: February 25, 1975, and in revised form: August 26, 1975

Prof. R. B. Elliott

The Univ. of Auckland

School of Medicine

85 Park Road

Auckland 3

New Zealand 